\title{
The ongoing naturalisation of Eucalyptus spp. in the Mediterranean Basin: new threats to native species and habitats
}

\author{
E. Badalamentia , D. Cusimano ${ }^{a}$, T. La Mantia $\mathbb{D}^{\mathrm{a}}$, S. Pasta ${ }^{\mathrm{b}}$, S. Romano ${ }^{c}$, A. Troia $\mathbb{D}^{\mathrm{d}}$ and V. Ilardi $^{\mathrm{c}}$
}

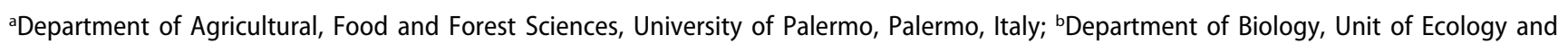
Evolution, University of Fribourg, Chemin du Musée, Fribourg, Switzerland; 'Department of Earth and Marine Sciences, University of Palermo, Palermo, Italy; ${ }^{d}$ Department of Biological, Chemical and Pharmaceutical Sciences and Technologies (STEBICEF), Section of Botany and Plant Ecology, University of Palermo, Palermo, Italy

\begin{abstract}
The genus Eucalyptus has been widely introduced into many regions of the world outside its native range and has become invasive in some Mediterranean biomes (e.g. in southern Africa and California). In the Mediterranean Basin and Europe, eucalypts were introduced at the end of the 18th century. However, natural regeneration events in these regions are recent in time and limited in terms of affected areas, except for the Iberian Peninsula. An updated overview about the natural spread of Eucalyptus species in Italy is still lacking. This paper aims to fill this knowledge gap, using both published data and unpublished field data regarding naturalisation events, with a specific focus on Sicily. Three species have naturalised on the island: Eucalyptus camaldulensis, E. globulus and E. occidentalis. According to our data, E. camaldulensis showed a clear 'switch' in the past decade towards naturalisation and invasive behaviour on the pebbly shores of watercourses that have a torrential rainfall regime and erodible substrates, threatening native plant communities and species. Alluvial forests with Alnus glutinosa were found to be particularly vulnerable to $E$. camaldulensis invasion. This is significant because the A. glutinosa communities are a native habitat of particular conservation value and protected under the Habitats Directive 92/43. The uncontrolled spread of Eucalyptus species may represent a higher threat to native biodiversity than previously considered. The situation in Sicily could be indicative of the invasion process by eucalypts currently ongoing around the Mediterranean Basin, the management of which requires special attention, urgent action and sound choices.
\end{abstract}

\section{KEYWORDS}

biological invasions; insular ecosystems; river red gum; Eucalyptus camaldulensis; Eucalyptus globulus; Eucalyptus occidentalis; Alnus glutinosa

\section{Introduction}

The genus Eucalyptus (Family Myrtaceae; L'Héritier de Brutelle 1788), consisting of more than 700 species (Paczkowska \& Chapman 2000; Slee et al. 2006), mostly trees native to Australia, has been widely introduced outside its native range, particularly during the last two centuries. The success of such introductions has to be attributed to the peculiar biological traits of eucalypts, such as rapid growth rate, ecological plasticity and pioneer features. The introductions have also been encouraged by the many utilities that eucalypts are able to provide, including forest products (cellulose, firewood, poles, essential oils, pulpwood), environmental applications (dune stabilisation, windbreaks, reclamation of marshlands), and ornamental and aesthetic values (Forsyth et al. 2004; Ritter \& Yost 2009; La Mantia 2013). The high growth rates of eucalypts place them among the woody species most frequently used worldwide for silviculture (Florence 1996), as well as for arboriculture and short rotation coppices. For these reasons, extensive plantations have been established in the Mediterranean Basin, particularly on the Iberian Peninsula, but also in southern Africa, California, China and Brazil.

Although the Eucalyptus genus is valued for its utilitarian traits, it is also represented in the Global Compendium of Weeds (Randall 2012), where more than 100 eucalypt species are listed. However, so far this genus is currently underrepresented in invasive alien flora databases worldwide (Richardson \& Rejmánek 2011). This is in contrast to other widely introduced tree species such as Acacia spp. and Pinus spp., both including a large number of well-known invasive taxa (e.g. Pasta et al. 2012; Badalamenti et al. 2014). This circumstance led Forsyth et al. $(2004$, p. 76$)$ to state about eucalypts: 'They have, however, been markedly less successful as invaders than several other tree genera (for example, pine trees in the genus Pinus) that have enjoyed similar levels of dissemination as aliens'.

Eucalypts mainly invaded the Mediterranean biomes of the world, but in the Mediterranean Basin natural reproduction events are recent in time and limited in terms of affected areas, except for the Iberian Peninsula (Andreu et al. 2009; Fernandes et al. 2016). The two most widespread species in the world are Eucalyptus globulus Labill. and Eucalyptus camaldulensis Dehnh., which have a different natural distribution range, reflecting auto-ecological differences (Burges 1968; Paczkowska \& Chapman 2000). Eucalyptus globulus has become naturalised in several areas with oceanic and sub-tropical climate, but also in Mediterranean countries such as Spain (Sanz-Elorza et al. 2001), Rhodes island in Greece (Galanos 2015) and Sicily (Italy) (Giardina et al. 2007). Eucalyptus camaldulensis showed a marked preference for Mediterranean-climate areas, including California, South Africa and the Mediterranean Basin (Ritter \& Yost 2009; Tererai et al. 2013), where it naturalised in Spain (Sanz-

CONTACT T. La Mantia tommaso.lamantia@unipa.it Department of Agricultural, Food and Forest Sciences, University of Palermo, Viale delle Scienze Ed. 4, I-90128 Palermo, Italy 
Elorza et al. 2001), Portugal (Almeida \& Freitas 2006), Greece (Arianoutsou et al. 2010), North Africa (Vilà et al. 1999) and Italy (Celesti-Grapow et al. 2010).

Some consistent patterns have been found in eucalypt invasion worldwide. In many areas their current invasive status is still under debate, and subject to discussions and revision. In South Africa, seven Eucalyptus species had been listed in the Conservation of Agricultural Resources Act 1983 (Act No. 43), and were subject to stringent limitations for the cultivation and trade to prevent their further spread. However, a recent paper showed that only E. camaldulensis, Eucalyptus grandis W.Hill and Eucalyptus lehmannii (Schauer) Benth. have been considered invasive (Forsyth et al. 2004). Eucalyptus camaldulensis is also regarded as transformer species (sensu Pyšek et al. 2004), due to its ability to deeply change the structure and functioning of riparian habitats, as well as seriously threatening native biodiversity.

In California, 374 Eucalyptus species have been introduced since 1853 (Ritter \& Yost 2009). Among them, however, only 18 species have found suitable conditions for natural regeneration and survival outside cultivation, becoming naturalised; the two most common species are E. camaldulensis and E. globulus. Both species are considered harmful aliens for the conservation of semi-natural and natural habitats in Spain (Sanz-Elorza et al. 2001). In Spain, the cost incurred for the control of eucalypts between 2000 and 2009 amounted to $€ 30$ million, about $60 \%$ of the total costs incurred for all the invasive alien plants (Andreu et al. 2009). In Malta, the propagation, sowing and planting, import/export, transport and sale of E. camaldulensis and Eucalyptus gomphocephala A. Cunn. ex DC. are prohibited, due to their negative ecological impacts (MEPA 2013). Portugal deserves a particular mention, probably being home of the first known naturalisation event of eucalypts in Europe, concerning E. globulus in 1943 (Almeida \& Freitas 2006). Eucalyptus camaldulensis was observed as naturalised about 30 years later, and four other species by the end of the century. However, the current threat posed by eucalypts for native ecosystems conservation is still debated in that country (Fernandes et al. 2016). Although the ability of seed dispersal by different Eucalyptus species has been investigated within native ranges (e.g. Cremer 1977), there are few quantitative studies of dispersal ability and the establishment of seedlings in the secondary range. Systematic surveys of $E$. globulus under natural conditions have only recently shown that the species has a limited ability to invade new areas, despite possessing an outstanding resistance to wildfires and human disturbance (Catry et al. 2015; Fernandes et al. 2016).

All the evidence suggests that the naturalisation of eucalypts worldwide is a fairly recent process, which has significantly increased since the end of the last century. Such observation has stimulated research, debates and discussions about the current status, the future trends and potential risks associated with eucalypt invasion worldwide, as well as management implications. However, the knowledge necessary to address these issues in Sicily and Italy is still lacking.

This study aims to provide an updated overview of the knowledge about the introduction history and naturalisation events for Eucalyptus species in Italy and Sicily. It includes a thorough review of the available literature and provides new additional data from two decades of field observations. The information collected has been used to identify the potential risks posed by eucalypt invasion to the conservation of native biodiversity and ecosystem functioning and develop alert levels and management options. We conclude that as eucalypts occur naturally in areas with a Mediterranean climate, they may represent a higher threat than previously thought or recorded in invasive checklists.

\section{Materials and methods}

The widely accepted classification of alien species by Pyšek et al. (2004) was used in this study. Casual alien plants are defined as those that give rise only to ephemeral and occasional phenomena of natural regeneration, relying on repeated introductions for their persistence. Naturalised plants may form self-replacing populations for at least 10 years without direct human intervention but only invasive taxa are able to actively spread into new habitats, and at considerable distances from the mother plants. To identify Eucalyptus taxa as casual, naturalised or invasive in Mediterranean Europe, the information available in the most recent non-native flora databases, at European (DAISIE 2009), national (Viegi et al. 1974; Celesti-Grapow et al. 2010) and regional level (Raimondo et al. 2004), was primarily considered. Other specific contributions concerning the regional non-native floras, including Eucalyptus species (e.g. Camarda et al. 2016), were also taken into account. For Sicily, the most updated regional checklists were considered (Giardina et al. 2007; Raimondo et al. 2010), along with other publications about non-native or ornamental flora reporting eucalypts (e.g. Domina \& Mazzola 2008).

Eucalypt natural regeneration has rarely been explicitly cited in the main literature, either at national or regional level. Thus, an in-depth investigation in the phytosociological literature was carried out looking for any statement or evidence about Eucalyptus naturalisation. Extensive research effort was also carried out in grey literature, for instance consulting many theses about eucalypts discussed at the University of Palermo during recent years. Finally, all the papers related to eucalypts cultivation in Sicily and Italy were accessed (e.g. Ciancio et al. 1984; La Mantia 2013).

In addition to the literature and database searches, information on the natural spread of Eucalyptus species in Sicily was collected from data and unpublished reports from about 20 years of field observations carried out by the authors and other expert colleagues. For field observations, the following standard protocol was considered:

(1) Only individuals originating from seed, at least $1 \mathrm{~m}$ high (such that they are definitely established) and at least $5 \mathrm{~m}$ away from the most likely mother plants were taken into account

(2) Isolated individuals and clusters of individuals were distinguished, the latter being composed of more than five individuals.

Moreover, for $E$. camaldulensis natural regeneration sites we distinguished the following habitats:

- Artificial/urban which included the man-made habitats and artificial surfaces such as city walls, sidewalks, etc. 
- Maquis which included the natural vegetation aspects characterised by Mediterranean evergreen sclerophyllous shrubs and trees

- Plantation which included the afforested/reforested sites where eucalypts were frequently used in Sicily

- Riparian which included the natural habitats characterised by the presence of streams or rivers

- Roadsides which are road borders out of urban areas with usually shallow, disturbed and erodible soils.

Taxonomic nomenclature mainly followed Brooker (2000) and recent databases (DAISIE 2009; The Plant List 2013).

\section{Results \\ Historical remarks about Eucalyptus spp. introduction in Europe}

The introductions in Europe of Eucalyptus spp. began at the end of the 18th century, following the expeditions that led to Captain Cook's discovery of Australia (for more details about the introduction history in Europe see Silva-Pando \& Pino-Pérez 2016). Eucalyptus obliqua L'Hér. was the first species introduced, cultivated in the greenhouse at the Kew Botanical Gardens, London, in 1774 (Aiton 1789). By the end of the century, reports suggest that only Eucalytpus robusta Sm. and Eucalyptus resinifera Sm. had been planted outside at the Royal Gardens of the Royal Palace of Caserta (Italy) in 1782 (Terracciano 1876), and in the Kew Botanical Gardens in 1788 (Aiton 1811), respectively. Silva-Pando and Pino-Pérez (2016), however, argued that the date of the first planting outdoors of $E$. robusta in Italy should be postponed for 10 years (1792), to be consistent with the period of introduction at the Kew Gardens. However, Terracciano $(1876,1880)$, clearly stated that $E$. robusta was directly introduced from Australia, concurrent with the construction of the English garden of the Royal Palace of Caserta, which began in 1782, as also confirmed by other references (e.g. Moggi 1957).

During the 1800 s, E. globulus, Eucalyptus capitellata Sm., E. obliqua and Eucalyptus paniculata Sm. were also introduced to the Caserta Royal Gardens (Terracciano 1880). In the first three decades of the 19th century, only three other eucalypt species were introduced in Italy, namely Eucalyptus aromatica (Salisb.) Domin (in 1810), Eucalyptus resinifera Sm. and Eucalyptus saligna Sm. (both in 1812) (Agostini 1953). Eucalyptus camaldulensis, nowadays the most widespread species in Italy, was introduced in approximately 1832 . The 'Hortus camaldulensis' of Naples was one of the main sites of introduction of Eucalyptus species in Italy; at that time already hosting ten species (Dehnhardt 1832). During the same period, several other species were also introduced in the northern regions of Italy, such as Piedmont, Liguria, Tuscany and Lazio, especially in gardens, private villas and botanical gardens exclusively for ornamental purposes (Ciancio et al. 1984; Maniero 2000). From the second half of the 1800s onwards, eucalypts began to be used for a number of purposes, such as reclamation of marshes, along railway lines, as windbreaks, as well as in the massive reforestation interventions mainly aimed at soil protection and slopes stabilisation (Moggi 1957; Ciancio et al. 1984; La Mantia 2013).
In the early 20th century, E. globulus, E. robusta and Eucalyptus amygdalina Labill. were among the most widely cultivated species in Italy for the balsamic and antiseptic properties of the eucalyptol and for the reclamation of marshlands as supposed antimalarial remedy (Paoletti 1900-1902). Twenty-three Eucalyptus species were cultivated in the western Ligurian Riviera, and many more were tested as species of ornamental interest (Berger 1912). Many of these species, however, had no real economic and commercial importance, especially in sectors other than forestry. Subsequently, efforts were focused on species suitable for forest use, taking into account all the ecological constraints for the growth and survival. The large use of Eucalyptus species in reforestation of denuded and unstable slopes and of coastal mobile dunes of southern Italy, and of Sicily in particular, facilitated the spread of the most suitable species for protective and productive interventions (Ciancio et al. 1984; La Mantia 2011). This change in the prevailing purpose of the introduction caused a significant spread of $E$. camaldulensis in southern Italy (Agostini 1953), and played a prominent role in increasing its chance of naturalisation and establishment in semi-natural and natural habitats, with related ecological risks.

Currently, 14 species of Eucalyptus are recognised as naturalised in Europe and Italy (Table 1). Of these, however, only half are reported in the database compiled at European level by experts based on personal reports and, in part, on published bibliographic material (DAISIE 2009). Three species (Eucalyptus botryoides Sm., Eucalyptus rudis Endl. and Eucalyptus viminalis Labill.) are reported only in Sicily, while Eucalyptus occidentalis Endl. is found in the wild only in Calabria and Sicily. The two most widespread species in Europe are E. globulus and E. camaldulensis, occurring in several countries of the Mediterranean Basin, as well as in different Italian regions.

Table 1. Checklist of Eucalyptus spp. growing wild in Europe and Italy

\begin{tabular}{|c|c|c|}
\hline Species & Europe $^{1}$ & Italy $^{2}$ \\
\hline Eucalyptus amygdalina & $x$ & - \\
\hline E. botryoides & - & $\begin{array}{r}\text { n.s.: } S I C^{\mathrm{a}} \\
\text { C: } S A R^{b}\end{array}$ \\
\hline E. camaldulensis & $x$ & $\begin{array}{r}\text { C: ABR', BAS, CAL, CAM, LAZ, LIG, } \\
\text { MOL, SAR }\end{array}$ \\
\hline E. globulus & $x$ & $\begin{array}{r}\text { N: APU, SIC, TUS } \\
\text { n.s.: APU' }{ }^{\mathrm{d}} \text { BAS }, \text { SIC }^{\mathrm{a}} \\
\text { C: CAL, CAM, LAZ, LIG, SAR } \\
\mathbf{N}: \text { TUS }^{\mathrm{d}}\end{array}$ \\
\hline E. gomphocephala & $x$ & $\begin{array}{l}\text { n.s.: } S C^{\mathrm{a}} \\
\text { C: } S A R^{\mathrm{b}}\end{array}$ \\
\hline E. gunnii Hook. f. & $x$ & - \\
\hline E. johnstonii Maiden & $x$ & - \\
\hline E. pulchella Desf. & $x$ & - \\
\hline E. occidentalis & - & $\begin{array}{l}\text { n.s.: } \text { SIC }^{\mathrm{a}} \\
\text { C: } \text { CAL }\end{array}$ \\
\hline E. robusta & $x$ & C: $S A R^{b}$ \\
\hline E. rudis & - & $\begin{array}{c}\text { n.s.: } S I^{a} \\
\text { C: } S A R^{b}\end{array}$ \\
\hline E. sideroxylon & $x$ & C: $S R^{b}$ \\
\hline E. tereticornis & $x$ & C: $S A R^{b}$ \\
\hline E. viminalis & - & n.s.: $S C^{a}$ \\
\hline
\end{tabular}

${ }^{1}$ Europe: DAISIE (2009).

${ }^{2}$ Italy: Celesti-Grapow et al. (2010), ${ }^{a}$ Raimondo et al. (2010), ${ }^{b}$ Bacchetta et al. (2009), 'Olivieri (2015), 'Lazzaro et al. (2014), 'Massarelli and Tomaselli (2010), 'Bellotti and Mininni (2004).

C, casual; N, naturalised; n.S., not specified. Italian regions: ABR, Abruzzo; APU, Apulia; BAS, Basilicata; CAL, Calabria; CAM, Campania; LAZ, Lazio; LIG, Liguria; MOL, Molise; SAR, Sardinia; SIC, Sicily; TUS, Tuscany. 


\section{The history of naturalisation events in Italy}

The early signs of spontaneous reproduction from seed by Eucalyptus species in Italy date back only to the middle of the 20th century. During the years 1946/1949, E. camaldulensis (old name E. rostrata Schltdl.) was observed to grow spontaneously on the walls of Rome (Anzalone 1951). Later, Puccini (1950) observed natural regeneration from seed by $E$. camaldulensis, E. globulus and E. robusta in several orchards and botanical gardens of the western Ligurian Riviera. This is probably the first ascertained report about the naturalisation of eucalypts under field conditions for the whole national territory. A further confirmation of the rarity of the process comes from Moggi (1957), who considered the possibility of eucalypts to reproduce autonomously and to disperse seeds in Italy to be rare and accidental. He described the area of the 'Fattoria Le Casette' (Massaciuccoli, Lucca), along the coast of the Tuscan-Lazial Maremma, as the only site in Italy where $E$. camaldulensis seedlings are able to establish, showing a good ability to naturally reproduce.

Afterwards, the Italian checklist of non-native flora by Viegi et al. (1974) reported naturalised E. camaldulensis, $E$. globulus and E. robusta, and another 16 Eucalyptus species as only cultivated. However, scrutiny of the references listed in the checklist raises doubt about the effective invasive status reached at that time by these species at the national level. Most of the bibliographic references clearly refer to individuals cultivated for ornamental purposes, for protective afforestation/reforestation (Arrigoni 1964; Fenaroli 1970) or for phytoalimurgic use (Catanzaro 1968). In some cases, the explicit statement that spontaneous individuals are present is lacking, leaving the strong suspicion that they were only cultivated (Pizzolongo 1960; Fabbri 1963). Hence, the only explicit early references to natural regeneration from seed remain those of Puccini (1950) and Moggi (1957).

Pignatti (1982, p. 149) stated in the Flora of Italy (our translation): 'They are able to set seeds, at least in limited quantities, but seedlings coming from spontaneous seed dispersal are not observed in the wild; therefore, this genus does not tend to become naturalised in Italy, and its persistence is conditioned by man'. However, at the same time, evidence of naturalisation was observed in some experimental plots of E. camaldulensis and E. globulus in inland areas of Sicily, and at Badia di Paola (Cosenza) in Calabria (Ciancio et al. 1984). Spontaneous seedlings were later reported within areas reafforested with $E$. occidentalis in Calabria (Cantore et al. 1994) and E. camaldulensis in Sardinia (Mossa et al. 1996). Importantly, the first of these reports (Cantore et al. 1994) anticipated the date of the first observation of natural regeneration by $E$. occidentalis in Italy (Caruso 2007). Most of the reports of naturalisation events by Eucalyptus species are from the last 20 years, and mainly refer to $E$. camaldulensis, in part to E. globulus, and only marginally to $E$. occidentalis.

Campania, one of the leading Italian regions for the introduction of eucalypt taxa in Europe, has also been one of the most affected by naturalisation processes. There, eucalypts invaded both ruderal habitats, uncultivated lands, railway embankments and afforestations, but also natural habitats and riparian vegetation (Stinca et al. 2015; and references within; De Natale \& Strumia 2007). In similar forest habitats, E. globulus was found growing in the wild in Lazio (Anzalone et al. 2010). Interpretations of the naturalisation of eucalypts in Italy are often conflicting and confused. For example, two recent checklists of alien plants in Sardinia have reported different results. Bacchetta et al. (2009) included eight species (E. botryoides, E. gomphocephala, Eucalyptus tereticornis Sm., E. rudis, Eucalyptus sideroxylon A. Cunn. ex Woolls and E. robusta) as casual, and E. camaldulensis and E. globulus as naturalised. In contrast, the regional alien flora by Camarda et al. (2016) considers only E. camaldulensis and E. globulus as casual.

Conflicting results have also been found for Tuscany. The Italian checklist of non-native flora (Celesti-Grapow et al. 2010) did not report any Eucalyptus species for that region, consistent with the opinion by Arrigoni and Viegi (2011), who considered the chance of naturalisation by E. camaldulensis in the region as very low. However, E. camaldulensis and $E$. globulus have been subsequently reported as naturalised on some islands of the Tuscan archipelago (Lazzaro et al. 2014). Some reports note that eucalypts are considered worthy of protection from the spread of other non-native taxa, in particular pathogenic insects, because of their recognised landscape and ornamental value (Giannini et al. 2013).

The review of this recent literature points out the complexity of the issues related to alien species management of species such as eucalypts, which may play an important ecological and landscape role in some environmental contexts, but, at the opposite, may represent a serious threat to native biodiversity, especially in riparian habitats.

\section{The history of naturalisation of Eucalyptus species in Sicily}

The first introductions in Sicily of Eucalyptus species began almost 40 years after the introductions in Italy, dating back to the 1820s (Agostini 1953; Table 2). Eucalyptus capitellata, E. resinifera, E. robusta and Eucalyptus piperita Sm. (old name E. scabra Dum. Cours.), present in 1821 at the Royal Garden of Boccadifalco near Palermo (Gussone 1821), were the first introduced species. Eucalyptus globulus was probably introduced between 1863 and 1868, being, respectively, absent (Todaro 1862) and present (Todaro 1868) among cultivated taxa within the Botanical Garden of Palermo. Ostinelli (1910), conversely, would bring the introduction of this species back to 1810; the first occurrence of a eucalypt species in Sicily. However, there is no other evidence to corroborate this hypothesis. At the end of the 19th century, nine species of Eucalyptus were cultivated at the Botanical Garden of Palermo (Borzì et al. 1900).

Eucalypts were soon regarded as promising and multipurpose trees (Direzione dell'Orto Botanico di Palermo 1908 ), useful for timber production (E. camaldulensis and $E$. viminalis), extraction of tannin dye (Eucalyptus diversicolor $\mathrm{F}$. Muell.) and for aromatic and balsamic essences ( $E$. amygdalina, Eucalyptus citriodora Hook. and E. globulus). Eucalypts were widely used in Sicily in reforestation and the establishment of hedges along railway tracks; such activities have been carried out since 1880 by the Italian State Railways, mainly using E. camaldulensis and E. occidentalis (Moggi 1957). Due to their pioneer nature, rapid initial growth and marked resistance to drought, eucalypt plantations, especially after World War II, were largely established in Sicily for protective reforestation interventions, particularly in marginal and agricultural abandoned areas (La Mantia 2013). As a consequence, the area covered by eucalypts in Sicily was 
Table 2. Native range and introduction date of the most common Eucalyptus species occurring in Sicily

\begin{tabular}{|c|c|c|}
\hline Species & Native range & Introduction date in Sicily (reference) \\
\hline Eucalyptus amygdalina & Tasmania $^{a}$ & 1899 (Borzì et al. 1900) \\
\hline E. botryoides & SE Australia ${ }^{\mathrm{b}}$ & Around 1927 (Moggi 1957) \\
\hline E. camaldulensis & Australia (widespread) ${ }^{\mathrm{b}}$ & 1903 (old name Eucalyptus rostrata; Borzì et al. 1904) \\
\hline E. diversifolia & Western Australia ${ }^{c}$ & 1827 (Tineo 1827) \\
\hline E. globulus & SE Australia, Tasmaniab & 1863-1868 (Todaro 1862, Todaro 1868) \\
\hline E. globulus subsp. maidenii (F.Muell.) J.B.Kirkp. & SE Australia ${ }^{b}$ & Around 1927 (Pavari \& De Philippis 1941) \\
\hline E. gomphocephala & SW Australia ${ }^{b}$ & Around 1925-1926 (Moggi 1957) \\
\hline E. occidentalis & Western Australia ${ }^{c}$ & 1913 (Borzì et al. 1914) \\
\hline E. resinifera & E Australia ${ }^{b}$ & 1821 (Gussone 1821) \\
\hline E. robusta & E Australia ${ }^{b}$ & 1821 (Gussone 1821) \\
\hline E. rudis & Western Australia ${ }^{c}$ & Around 1927 (Pavari \& De Philippis 1941) \\
\hline E. viminalis & S and E Australia, Tasmania ${ }^{\mathrm{b}}$ & 1875 (Todaro 1875) \\
\hline E. $\times$ trabutii Trabut & Hybrid of Algerian origin ${ }^{b}$ & Around 1949 (Moggi 1957) \\
\hline
\end{tabular}

airkpatrick and Backhouse (2007)

bBurges (1968).

'Western Australian Herbarium (1998).

significantly increased. According to the most recent regional forest inventory, eucalypt plantations occupy an area close to 40000 ha, equal to more than one third of the total area occupied by plantations and approximately to $15 \%$ of the area covered by forests in Sicily (Camerano et al. 2011).

The early naturalisation signs of eucalypts in Sicily were observed in the early 1980s in the E. camaldulensis and $E$. globulus reforestations of Piazza Armerina (Enna province) (Ciancio et al. 1984; Table 3). Natural regeneration from seed was not particularly abundant, having been considered insufficient to replace, from the productive point of view, the coppice shoots originated from the decaying stumps. More than 10 years later, some young individuals of $E$. camaldulensis were found in a reforestation near the 'Gorgo di Santa Rosalia', a little temporary pond on Mount Pellegrino near Palermo (Naselli Flores et al. 2002). Only four other reports about $E$. camaldulensis have been found in literature, but they often lack specific information on affected habitats and level of spread. As far as E. globulus is concerned, in addition to the report by Ciancio et al. (1984), Cavarretta and Saporito (1998) observed natural regeneration within a pure plantation in Enna province. The authors also stated that it was one of the few areas where such natural processes had been noted in Sicily. More recently, Licandro et al. (2011) have included this species in the floristic list of the Nature Reserve 'Laghetti di Marinello' (Messina province). No other geographically explicit reference to naturalisation cases of Eucalyptus in Sicily was found. Indeed, E. botryoides, E. gomphocephala, E. occidentalis, E. rudis and E. viminalis are reported as rarely naturalised in Sicily by Giardina et al. (2007), but specific information is not given. Also, such eucalypt taxa have never been reported in Italian literature (Table 3), as well as during personal field observations by the authors, except E. occidentalis (Table 4).

A summary of the regional locations where spontaneous eucalypt individuals were observed, is provided in Table 4. The rather frequent observation of seedlings along roadsides seemed to confirm the consideration by Florence (1996, p. 146): 'the undisturbed floor of the eucalypt forest is not suitable for the establishment of seedlings'. However, natural regeneration within reforestations has been observed with increasing frequency, indicating a stark acceleration of the invasive process in Sicily. The results of field observations collected over 30 years suggest that three species have naturalised in Sicily (sensu Pyšek et al. 2004): E. camaldulensis, E. globulus and E. occidentalis. Up to now, they do not seem able to actively spread a great distance from the introduction areas so they cannot be considered invasive. However, the observations indicate that within riparian habitats $E$. camaldulensis should be regarded as locally invasive. Eucalyptus botryoides, E. gomphocephala, E. rudis and E. viminalis, reported in the two most recent checklists of regional flora (Giardina et al. 2007; Raimondo et al. 2010), could be prudentially considered as casual, because information about the sites of spontaneous reproduction is still lacking.

\section{The naturalisation of Eucalyptus species in Sicily: an ecological overview with a special focus on Eucalyptus camaldulensis}

The three naturalised species of Eucalyptus in Sicily have reached hitherto different levels of spread, showing significant differences in the spatial and temporal dynamics of the respective invasive processes. The natural spread of $E$. globulus is currently very limited, as it is only found within reforestations and anthropic habitats. Eucalyptus occidentalis is exclusively used in plantations, where it naturally occurs with a relatively high frequency. For this species it is important to monitor its demographic trend and its ability to invade protected natural areas. The naturalisation and spread of $E$. camaldulensis is, however, probably of most concern. More than 50 unpublished sites of naturalisation of Eucalyptus spp. have been reported in Sicily (Table 4), and more than $85 \%$ of the new records involve E. camaldulensis, particularly from 2010 onwards (Fig. 1).

Eucalyptus camaldulensis shows a large ecological plasticity and is mainly found in the central and north-western sectors of the island (Fig. 2). It has mainly invaded synanthropic habitats, such as roadsides, urban sites and plantations, together accounting for about $80 \%$ of the total records. However, the remaining $20 \%$ of the records are in natural and semi-natural communities, particularly riparian native vegetation belonging to the phytosociological classes Salicetea purpureae Moor and Nerio-Tamaricetea Br.-BI. \& O. Bolòs (Fig. 3). This spread mainly affects the natural floodplains of watercourses with an irregular or seasonal flow, which are prevalent in the Mediterranean and Sicily. Here, E. camaldulensis seems to find ideal conditions for 
establishment and spreads especially along river shores and banks, according to its ecological requirements (Di Stefano 2002; Catelotti et al. 2015). Three significant cases of $E$. camaldulensis invasion in watercourses have been observed.

In the valley of 'Imera settentrionale' River, along the PalermoCatania motorway, the naturalised E. camaldulensis individuals tend to stand out isolated and dominant, except for some residual tracts where the riparian vegetation is still dominated by native poplars (Populus nigra L. and Populus alba L.). In the middle stretch of the river there are now dozens of naturalised individuals. Direct field observations allowed us to appreciate the abundant seed production by mature eucalypt individuals, as well as the tendency of seedlings and saplings to become established and dominant. Natural regeneration is particularly abundant downstream of mature individuals about 20 years old, having diameters at breast height ranging from 30 to $50 \mathrm{~cm}$. In this study site, $E$. camaldulensis competes with a number of native species such as $P$. nigra, Spartium junceum L., Nerium oleander L., and Calicotome infesta (C. Presl) Guss. subsp. infesta. Eucalyptus camaldulensis seedlings also tend to invade the river terraces, where they compete with Helichrysum italicum subsp. siculum (Jord. \& Fourr.) Galbany, L. Saèz and Benedi. It is noteworthy that other non-native woody species are spontaneously reproducing in the same habitat, namely Acacia saligna (Labill.) H.L. Wendl. and Sesbania punicea (Cav.) Benth., both showing invasive tendencies.

Along the Castelbuono torrent, many naturalised $E$. camaldulensis individuals, more than $20 \mathrm{~m}$ high and about 15-20 years old, were observed. In this watercourse, E. camaldulensis competes with many native riparian species such as $P$. alba, Populus $\times$ canescens Aiton (Sm.), P. nigra, Salix pedicellata Desf., Salix alba L., Salix purpurea L., and Fraxinus angustifolia Vahl.. With its columnar-assurgent posture, E. camaldulensis competes for light with the largest poplars, but it seems to overcome and dominate all the other woody species, especially in the meanders. Its spread here is of particular concern because the local native flora is quite diversified by the presence of $F$. angustifolia, Tamarix africana Poir. and Bupleurum fruticosum L.

In the Alcantara River, the occurrence of isolated mature Eucalyptus individuals, reaching heights up to $12-15 \mathrm{~m}$ after about 10-15 years, is appreciable also at a great distance, especially where the river bed spreads out and a pebbly shore emerges. Eucalyptus camaldulensis is established in the upper part of the river basin, where its spread directly threatens peculiar aspects of native riparian vegetation dominated by Alnus glutinosa (L.) Gaertn., such as the priority habitat ' $91 \mathrm{EO}^{*}$-Alluvial forests with Alnus glutinosa and Fraxinus excelsior (Alno-Padion, Alnion incanae, Salicion albae)', in accordance with the Habitats Directive EEC/92/43. Alnus glutinosa is rare and in decline in Sicily, where its natural distribution is currently limited to few stations in the Peloritani mountains (La Mantia \& Pasta 2004). In the valley of high Alcantara River, the watercourse assumes the appearance of a so-called 'Fiumara', and the clear water supports one of the most preserved populations of $A$. glutinosa in Sicily.

In the investigated habitats, E. camaldulensis is actively replacing native tree species, significantly altering the local plant communities and ecosystem functioning (Richardson et al. 2007; Tererai et al. 2013). Riparian habitats, with each flood event providing new ecological niches, appear to benefit invasive alien species over native species (Hood \& Naiman 2000; Catry et al. 2015). Eucalyptus camaldulensis shows a great ability to exploit disturbed areas through 
Table 4. New records of naturalisation cases of Eucalyptus spp. in Sicily

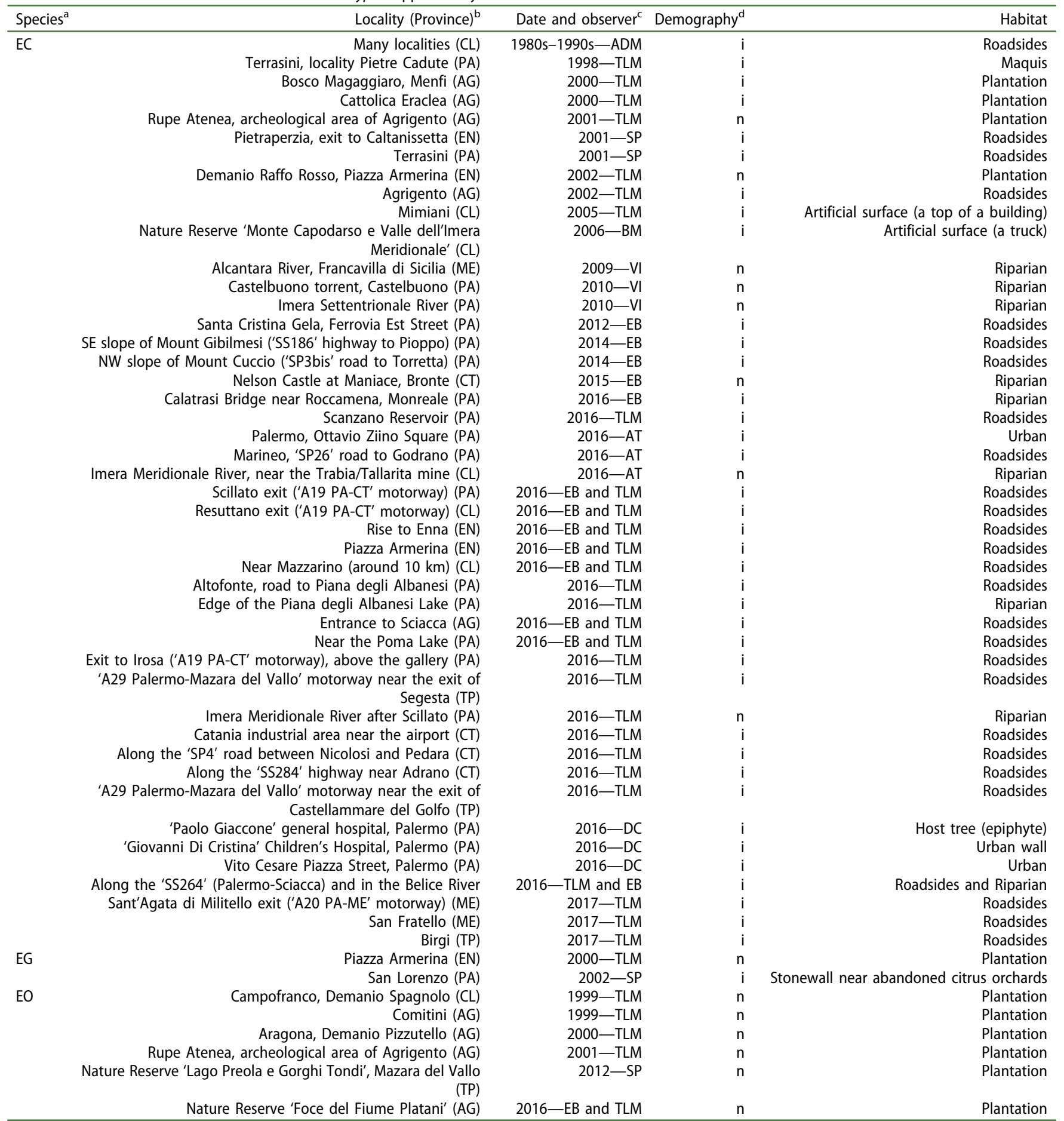

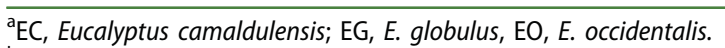

${ }^{\mathrm{b}} \mathrm{AG}$, Agrigento; CL, Caltanissetta; CT, Catania; EN, Enna; ME, Messina; PA, Palermo; TP, Trapani.

'ADM, Angelo Dimarca; AT, Angelo Troia; BM, Bruno Massa; DC, Dario Cusimano; EB, Emilio Badalamenti; SP, Salvatore Pasta; TLM, Tommaso La Mantia; VI, Vincenzo llardi.

$\mathrm{d}_{\mathrm{i}}$, isolated individuals, $\mathrm{n}$, nucleus/nuclei (more than five individuals).

rapid early growth rates (Fernandes et al. 2016), as it does in its native range (Sena Gomes \& Kozlowski 1980; Di Stefano 2002). Also, the allelopathic effects of tissues, soil and litter should be considered for their potential role in inhibiting native co-occurring species (Ruwanza et al. 2015). The flood events, which occur during the winter and spring seasons, may almost completely eliminate even the herbaceous plant communities, making large tracts of the river particularly exposed to $E$. camaldulensis invasion. It is likely that $E$. camaldulensis may grow faster than native co-occurring riparian species in Sicily, and this is one of the biological traits which may explain its invasive character in Sicily. However, whether or not there is a primary mechanism underlying its successful invasion of native riparian habitats is currently unknown.

\section{Discussion and conclusions}

The bibliographic and field surveys carried out allowed us to provide an account of the history of Eucalyptus spp. introduction, naturalisation and invasion in Europe, particularly 


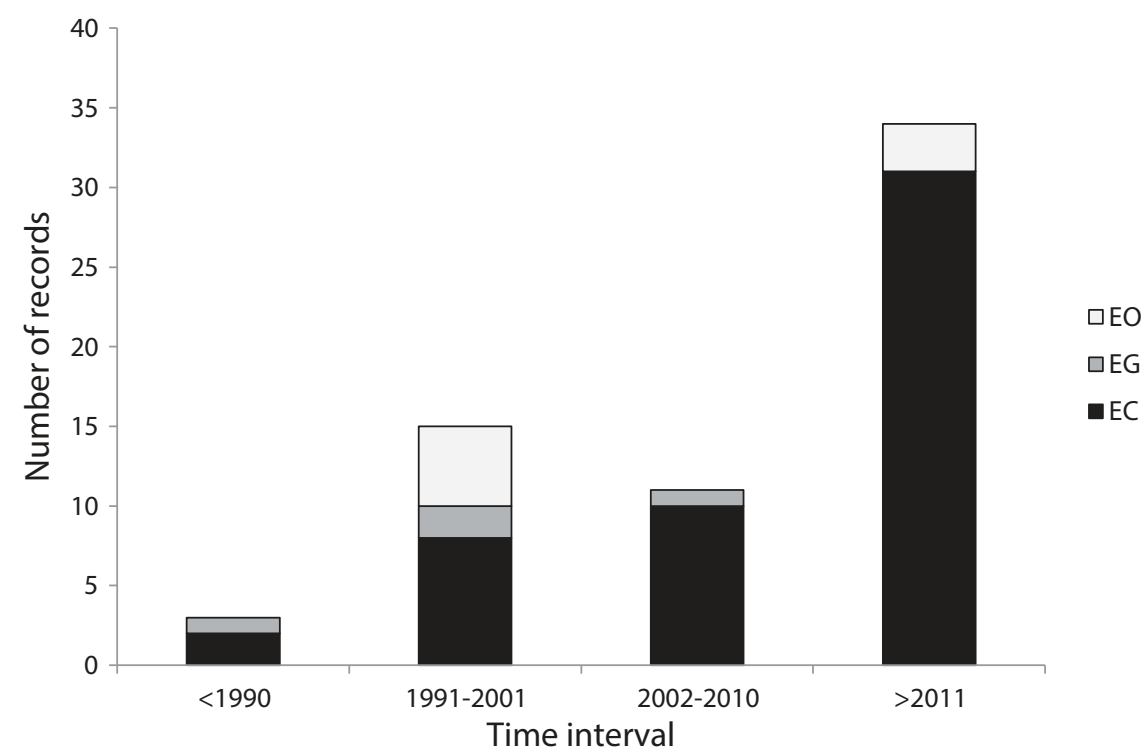

Figure 1. Temporal accumulation of records (see Table 4) of natural establishment of Eucalyptus camaldulensis (EC), E. globulus (EG) and E. occidentalis (EO) in Sicily

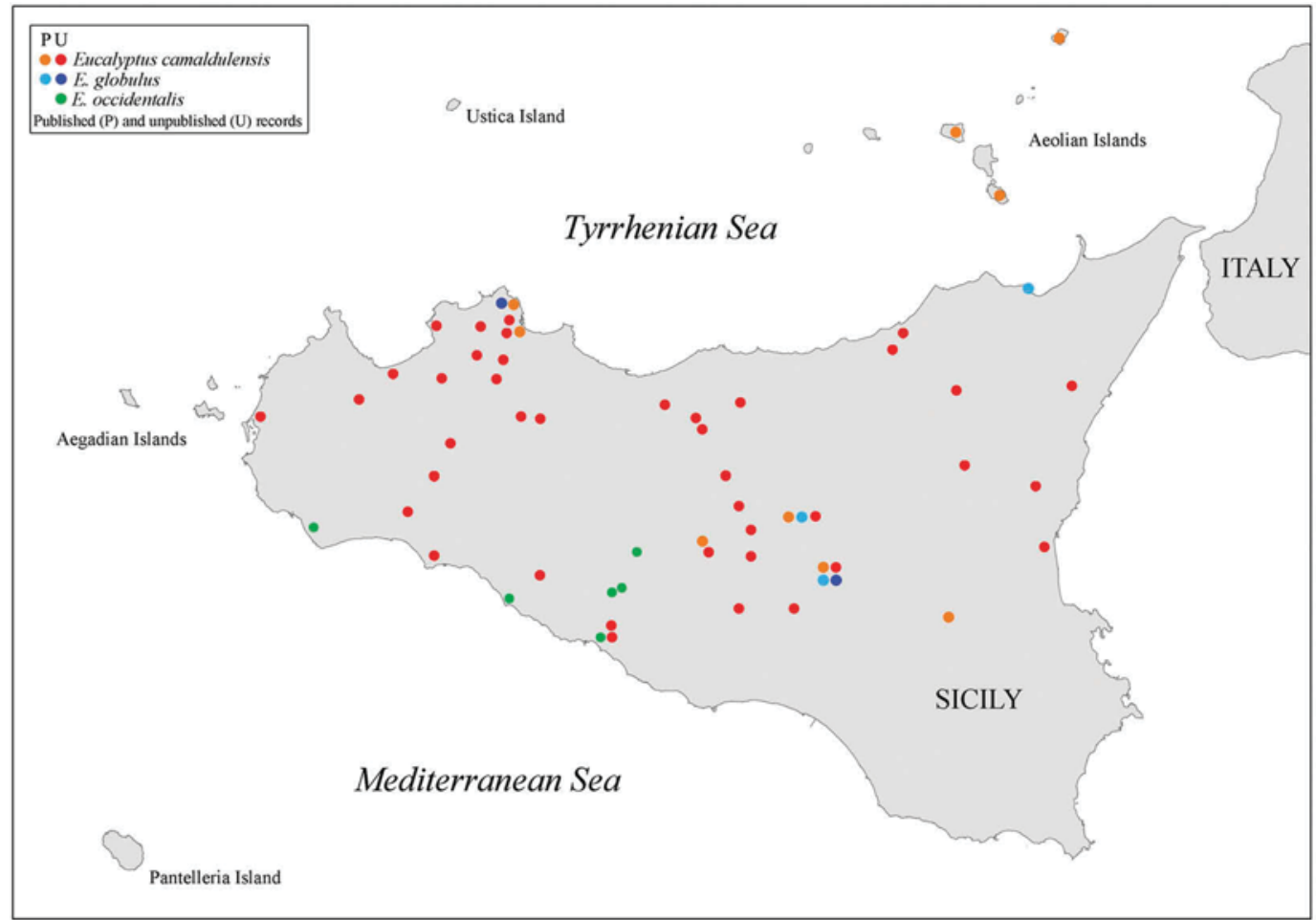

Figure 2. 'Natural' distribution of Eucalyptus spp. in Sicily

Italy and Sicily. Some of the recently observed cases need to be monitored and controlled as the spread of these alien species may represent a serious threat to the stability and integrity of native plant species and riparian phytocoenoses in the region.

Eucalypts have been planted worldwide for a number of purposes, significantly increasing the probability that they would become invasive somewhere (Lambdon et al. 2008). The propagule pressure, another key factor in the invasive process, has been high and continuous over time (Von Holle \& Simberloff 2005). As some eucalypt taxa are well adapted to Mediterranean climates, their naturalisation was not unexpected. However, a rather long lag phase occurred between the early introductions to different regions and the early signs of naturalisation (Aikio et al. 2010). For about a century and a half, the ecological conditions needed for viable seed production and for the survival and growth of Eucalyptus seedlings outside areas of cultivation were lacking. The invasive process has significantly acceleration in the last 10-20 years, as shown by the progressive increase of the records we collected in this study. This trend may be due to the increasing attention to the issue of biological invasions and their potential negative ecological effects, both at national and European level. However, Eucalyptus species effectively started to naturally reproduce and spread in Italy in recent decades, showing invasive dynamics very different from those of other non-native invasive woody plants which naturalised very quickly, such as Ailanthus altissima (Mill.) Swingle (Badalamenti et al. 2015).

The results of this review indicate that the naturalisation and invasive nature of $E$. camaldulensis in Sicily warrants 


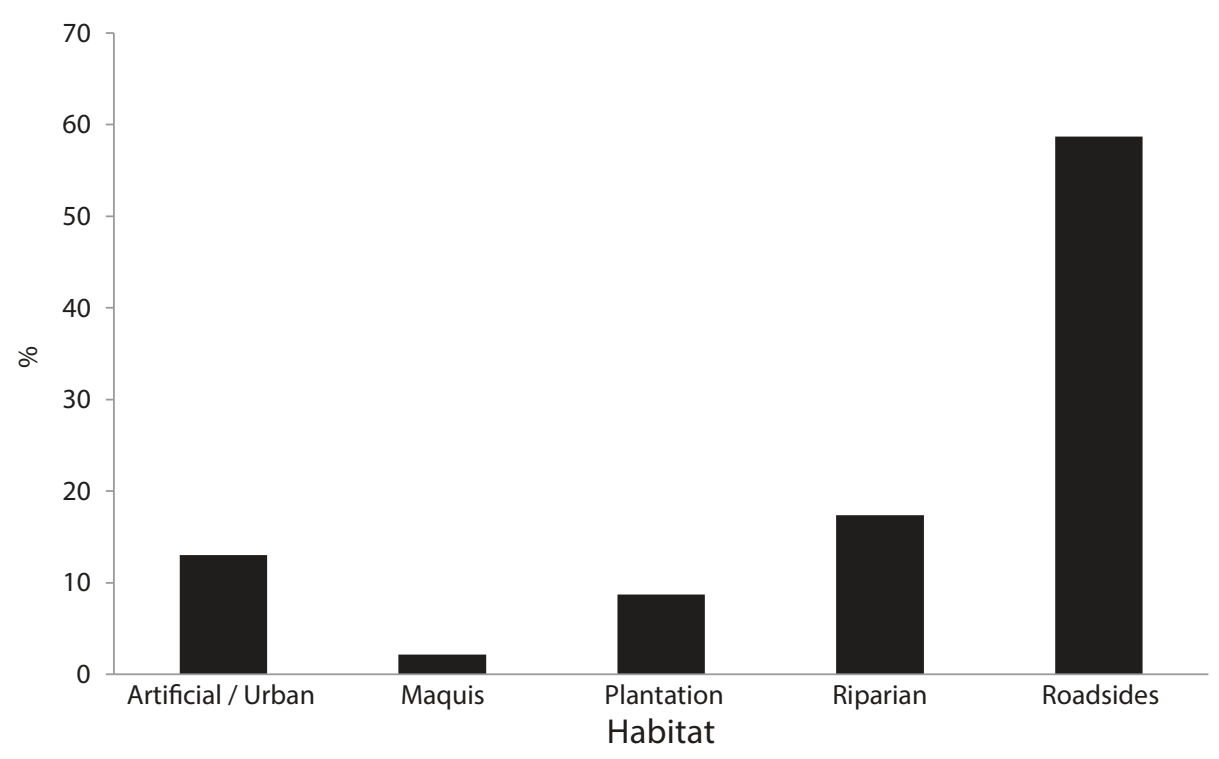

Figure 3. 'Habitat' preference by percentage of Eucalyptus camaldulensis records in Sicily

significant management consideration. After about two centuries of cultivation, E. camaldulensis is now showing clear invasive behaviour in the pebbly shores of watercourses that have a torrential regime and unstable substrates, where it may replace the local flora. It is unclear if this recent 'switch' towards invasion can be related to climatic changes, or to other abiotic or biotic factors; further investigation is needed. Of concern is the increasingly frequent and widespread observation of naturalised individuals in natural and semi-natural habitats. Despite this, Eucalyptus spp. are not listed among the invasive alien species capable of threatening native riparian habitats of unique conservation interest, despite their recognised vulnerability to plant invasions by other alien species (Angiolini et al. 2016). The information gathered in this review suggests that $E$. camaldulensis should be included among the potential threats to Mediterranean riparian habitats conservation, typically characterised by seasonal water runoff and fluctuation of available resources. In the absence of appropriate management and control strategies, the negative ecological effects of the natural spread of Eucalyptus species in Sicily, still largely unknown and probably underestimated, are bound to be considerable and long-lasting.

The control of $E$. camaldulensis is a difficult task to achieve, especially in long-time invaded areas where this species has become established and is outcompeting native coexisting species. The riparian habitats are difficult environments where the implementation of management intervention is complex. However, the adoption of an integrated management strategy may enable the control of this invasive species, as applied to other invasive species (Badalamenti \& La Mantia 2013). Such a strategy would include effective early detection and prompt eradication of $E$. camaldulensis in watercourses throughout the region followed by permanent monitoring, especially where eucalypt plantations are localised near watercourses. Also, the localised removal of mother plants established along riverbanks in the dry season may prevent seed entering the river, thus slowing down the overall invasive process.

The numerous unpublished reports concerning riparian habitats, highlight the urgent need to further investigate and analyse the invasion process by eucalypts and to assess the potential negative ecological impacts due to their uncontrolled spread. More attention should be paid to species that may reveal invasive behaviour in the near future, also in light of the ongoing climate change and of their large-scale occurrence in the Mediterranean Basin, including the southern and insular regions of Italy.

\section{Acknowledgements}

Special thanks are due to Dr. Giuseppe Occorso for scanning old slides of eucalypts plantations in Sicily and to Daniela Patti for her valuable support during bibliographic research. Many observations were carried out within the MIUR-PRIN project 'Climate change mitigation strategies in tree crops and forestry in Italy (CARBOTREES)'. We also thank the Editor and two anonymous reviewers for their useful suggestions which significantly improved the quality of the manuscript.

\section{Disclosure statement}

No potential conflict of interest was reported by the authors.

\section{Funding}

This work was supported by the MIUR-PRIN project 'Climate change mitigation strategies in tree crops and forestry in Italy (CARBOTREES) [20085FL4E4].

\section{ORCID}

T. La Mantia (D) http://orcid.org/0000-0002-7494-742X

A. Troia (D) http://orcid.org/0000-0001-5193-8865

\section{References}

Agostini R. 1953. Cenni storici sulla introduzione degli eucalitti in Italia. L'Italia Forestale e Montana. 8:117-122.

Aikio S, Duncan RP, Hulme PE. 2010. Lag-phases in alien plant invasions: separating the facts from the artefacts. Oikos. 119:370-378.

Aiton WT. 1789. Hortus Kewensis or catalogue of the plants cultivated in the royal botanic garden in Kew. Vol. II. London: George Nicol Printer. Aiton WT. 1811. Hortus Kewensis or catalogue of the plants cultivated in the royal botanic garden in Kew. Vol. III. London: Longman.

Almeida JD, Freitas H. 2006. Exotic flora of continental Portugal - a reassesment. Botanica Complutensis. 30:117-130. 
Andreu J, Vilá M, Hulme PE. 2009. An assessment of stakeholder perceptions and management of noxious alien plants in Spain. Environmental Management. 43:1244-1255.

Angiolini C, Lasen C, Paura B. 2016. 91E0* Foreste alluviali di Alnus glutinosa e Fraxinus excelsior (Alno-Padion, Alnion Incanae e Salicion albae). In: Angelini P, Casella L, Grignetti A, Genovesi P, editors. Manuali per il monitoraggio di specie e habitat di interesse comunitario (Direttiva 92/43/CEE) in Italia: habitat. ISPRA, Serie Manuali e Linee Guida, 142/2016. [accessed 2017 Apr 27]. Available from:http:// www.isprambiente.gov.it/public_files/direttiva-habitat/Manuale-1422016.pdf.

Anzalone B. 1951. Flora e vegetazione dei muri di Roma. Annali di Botanica (Roma). 23:393-497.

Anzalone B, Iberite M, Lattanzi E. 2010. La Flora vascolare del Lazio. Informatore Botanico Italiano. 42:187-317.

Arianoutsou M, Bazos I, Delipetrou P, Kokkoris Y. 2010. The alien flora of Greece: taxonomy, life traits and habitat preferences. Biological Invasions. 12:3525-3549.

Arrigoni PV. 1964. Flora e vegetazione della foresta di Pixinamanna (Sardegna meridionale). Webbia. 19:349-454.

Arrigoni PV, Viegi L. 2011. La flora vascolare esotica spontaneizzata della Toscana. Firenze: Regione Toscana.

Bacchetta G, Mayoral García Berlanga O, Podda L. 2009. Checklist de la flora exótica de Cerdeña (Italia). Flora Montiberica. 41(I-2009):35-61.

Badalamenti E, Gristina L, La Mantia T, Novara A, Pasta S, Lauteri M, Fernandes P, Correia O, Máguas C. 2014. Relationship between recruitment and mother plant vitality in the alien species Acacia cyclops A. Cunn. ex G Don. Forest Ecology and Management. 331:237-244.

Badalamenti E, La Mantia T. 2013. Stem-injection of herbicide for control of Ailanthus altissima (Mill.) Swingle: a practical source of power for drilling holes in stems. iForest. 6:123-126.

Badalamenti E, La Mantia T, Quatrini P. 2015. Arbuscular mycorrhizal fungi positively affect growth of Ailanthus altissima (Mill.) Swingle seedlings and show a strong association with this invasive species in Mediterranean woodlands. Journal of the Torrey Botanical Society. 142:127-139.

Bellotti A, Mininni D. 2004. Alberi della Basilicata: le principali specie sul territorio lucano. Potenza: Consiglio regionale della Basilicata.

Berger A. 1912. Hortus Mortolensis enumeratio plantarum in horto mortolensi cultarum. Alphabetical catalogue of plants growing in the garden of the late Sir Thomas Hanbury, at La Mortola, Ventimiglia, Italy. Hatton Garden: West, Newman \& Co.

Borzì A, Baldacci A, Mattei GE, Tropea A, Riccobono V, Riccobono A. 1914. Semina anni 1913 quae pro mutua commutuatione offeruntur. Bollettino del Regio Orto Botanico e Giardino Coloniale di Palermo. 1:1-82.

Borzì A, Terracciano A, Caldarera I, Cobau E, Riccobono V, Riccobono A. 1904. Index seminum anno 1903 collectorum quae pro mutua commutuatione offeruntur. Bollettino del R. Orto Botanico di Palermo. V (Appendice I):1-90.

Borzì A, Terracciano A, Cobau E, De Fonzo G, Riccobono V, Riccobono A. 1900. Index seminum anno 1899 collectorum quae pro mutua commutuatione offeruntur. Bollettino del R. Orto Botanico. IV(Appendice I):1-85.

Brooker MIH. 2000. A new classification of the genus Eucalyptus L'Hér. (Myrtaceae). Australian Systematic Botany. 13:79-148.

Burges NA. 1968. Eucalyptus L'Hér. In: Tutin TG, Heywood VH, Burges NA, Moore DM, Valentine DH, Walters SM, Webb DA, editors. Flora Europaea, Volume 2: Rosaceae to Umbelliferae. Cambridge: Cambridge University Press; p. 304-305.

Camarda I, Cossu TA, Carta L, Brunu A, Brundu G. 2016. An updated inventory of the non-native flora of Sardinia (Italy). Plant Biosystems. 150:1106-1118.

Camerano P, Cullotta S, Varese P. 2011. Strumenti conoscitivi per la gestione delle risorse forestali della Sicilia. Tipi Forestali. Assessorato Territorio e Ambiente, Regione Siciliana. Perugia: Litograf Editor s.r.I.

Cantore V, lovino F, Puglisi S. 1994. Influenza della forma di governo sui deflussi liquidi e solidi in piantagioni di eucalitti. L'Italia Forestale e Montana. XLIX(5):463-477.

Caruso G. 2007. Notulae: 1346-1349. Informatore Botanico Italiano. 39:401-435.

Catanzaro F. 1968. Piante officinali dell'isola di Pantelleria. Webbia. 23:135-148.
Catelotti K, Kingsford RT, Bino G, Bacon P. 2015. Inundation requirements for persistence and recovery of river red gums (Eucalyptus camaldulensis) in semi-arid Australia. Biological Conservation. 184:346-356.

Catry FX, Moreira F, Deus E, Silva JS, Águas A. 2015. Assessing the extent and the environmental drivers of Eucalyptus globulus wildling establishment in Portugal: results from a countrywide survey. Biological Invasions. 17:3163-3181.

Cavarretta D, Saporito L. 1998. Boschi artificiali della Sicilia. Aspetti selvicolturali e problematiche gestionali. In: Siciliana $R$, Demaniali AF, editors. Atti del secondo congresso di Selvicoltura: conservazione e miglioramento dei Boschi in Sicilia. Palermo: Azienda Foreste Demaniali; p. 57-102.

Celesti-Grapow L, Pretto F, Carli E, Blasi C, editors. 2010. Flora vascolare alloctona e invasiva delle regioni d'Italia. Roma: Casa Editrice Università La Sapienza.

Ciancio O, Mercurio R, Nocentini S. 1984. La sperimentazione di specie forestali esotiche in Italia. Risultati dopo un sessantennio. Annali Istituto Sperimentale per la Selvicoltura. XII e XIII:1981/1982.

Cremer KW. 1977. Distance of seed dispersal in eucalypts estimated from seed weights. Australian Forestry Research. 7:225-228.

DAISIE (Delivering Alien Invasive Species Inventory for Europe). 2009. Handbook of alien species in Europe. Dordrecht: Springer.

De Natale A, Strumia S. 2007. La flora della costa sabbiosa del Parco Nazionale del Cilento e Vallo di Diano (Salerno). Webbia. 62:53-76.

Dehnhardt F. 1832. Catalogus plantarum Horti Camaldulensis. Neapoli: Editio Secunda Auctior.

Di Stefano J. 2002. River red gum (Eucalyptus camaldulensis): a review of ecosystem processes, seedling regeneration and silvicultural practice. Australian Forestry. 65:14-22.

Direzione dell'Orto Botanico di Palermo. 1908. Colture coloniali presso il R. Orto Botanico di Palermo. Bollettino del Regio Orto Botanico e Giardino Coloniale di Palermo. VII(1-2-3):118-147.

Domina G, Mazzola P. 2008. Flora ornamentale delle isole circumsiciliane. Quaderni di Botanica Ambientale e Applicata. 19:107-119.

Fabbri F. 1963. Per una flora dell'isola di Montecristo. Le piante vascolari raccolte da A. Chiarugi nel Maggio del 1957. Giornale Botanico Italiano. 70:629-637.

Fenaroli L. 1970. Florae garganicae prodromus. Pars altera. Webbia. 24:435-578.

Fernandes P, Antunes C, Pinho P, Máguas C, Correia O. 2016. Natural regeneration of Pinus pinaster and Eucalyptus globulus from plantation into adjacent natural habitats. Forest Ecology and Management. 378:91-102.

Florence RG. 1996. Ecology and silviculture of Eucalyptus forests. Collingwood: CSIRO Publishing.

Forsyth GG, Brown PJ, Richardson DM, Van Wilgen BW. 2004. A rapid assessment of the invasive status of Eucalyptus species in two South African provinces: working for water. South African Journal of Science. 100:75-77.

Galanos C. 2015. The alien flora of terrestrial and marine ecosystems of Rodos island (SE Aegean), Greece. Willdenowia. 45:261-278. (Version of record first published online on 20 July 2015 ahead of inclusion in August 2015 issue).

Giannini F, Sposimo P, Giunti M, Piazzi A, Inghilesi A, Tricarico E. 2013. Linee Guida per la Strategia di contrasto alle specie aliene invasive nei sistemi terrestri insulari nell'Arcipelago Toscano. Progetto COREM 'Cooperazione delle Reti Ecologiche del Mediterraneo' Technical Report. doi:10.13140/2.1.1654.0164.

Giardina G, Raimondo FM, Spadaro V. 2007. A catalogue of plants growing in Sicily. Bocconea. 20:5-582.

Gueli L, Lo Giudice R. 2004. Studio ecologico e corologico della flora della città di Militello in Val di Catania (Sicilia orientale) con osservazioni sulle allergofite. Quaderni Botanica Ambientale E Applicata. 15:3-20.

Gussone G. 1821. Catalogus plantarum Quae asservantur in Regio Horto serenissimi Francisci Borbonii Principis Juventutis, in Boccadifalco, prope Panormum. Neapoli: Typis Angeli Trani.

Hood WG, Naiman RJ. 2000. Vulnerability of riparian zones to invasion by exotic vascular plants. Plant Ecology. 148:105-114.

Kirkpatrick JB, Backhouse S. 2007. Native trees of Tasmania. 7th Completely revised, Sandy Bay (Tasmania): Pandani Press.

L'Héritier de Brutelle CL. 1788. Sertum Anglicum, seu, Plantae rariores quae in hortis juxta Londinum: imprimis in horto regio Kewensi 
excoluntur, ab anno 1786 ad annum 1787 observatae. Paris: Petri Francisci Didot.

La Mantia T. 2011. I rimboschimenti delle dune. In: lentile R, Rühl J, La Mantia T, Massa B, editors. I cambiamenti nell'ecosistema della Riserva Naturale di Vendicari e gli effetti sull'avifauna. Palermo: Edizioni Danaus; p. 97-109.

La Mantia T. 2013. Storia dell'eucalitticoltura in Sicilia. II Naturalista siciliano. 37:587-628.

La Mantia T, Pasta S 2004. The Sicilian phanerophytes: still a noteworthy patrimony, soon a lost resource? In: Marchetti M.editor. Monitoring and indicators of forest biodiversity in Europe - from ideas to operationality. IUFRO Conference; 2003 Nov 15; Firenze. EFI Proceedings 51; p. 515-526.

Lambdon PW, Lloret F, Hulme PE. 2008. How do introduction characteristics influence the invasion success of Mediterranean alien plants?. Perspectives in Plant Ecology, Evolution and Systematics. 10:143-159.

Lazzaro L, Ferretti G, Giuliani C, Foggi B. 2014. A checklist of the alien flora of the Tuscan Archipelago (Italy). Webbia. 69:157-176.

Licandro G, Marino P, Raimondo FM. 2011. Flora e vegetazione della Riserva Naturale Orientata 'Laghetti di Marinello' (Sicilia nord-orientale). Informatore Botanico Italiano. 43:333-351.

Lo Giudice R, Cristaudo A. 2004. Chorological and ecological survey on the vascular and bryophytic flora in Enna territory (Erei Mountains, CSicily). Flora Mediterranea. 14:357-417.

Maniero F. 2000. Fitocronologia d'Italia. Padova: Edizioni Leo S. Olschki.

Massarelli C, Tomaselli V. 2010. Primo contributo alla conoscenza della flora del Parco naturale regionale 'Bosco dell'Incoronata' (Foggia puglia). Interdipendenze. 2:3-20.

MEPA (Malta Environment and Planning Authority). 2013. Guidelines on managing non-native plant invaders and restoring native plant communities in terrestrial settings in the Maltese Islands. La Valletta (Malta): Biodiversity Publications-ERA. [accessed 2017 Apr 27]. Available from:https://www.mepa.org.mt/file.aspx?f=9658.

Moggi G. 1957. Inventario delle specie del genere Eucalyptus esistenti in Italia. Pubblicazioni Centro Sperimentale Agricolo e Forestale Ente Nazionale per la Cellulosa e per la Carta. 1(1956):5-53.

Mossa L, Bacchetta G, Angiolino C, Ballero M. 1996. A contribution to the floristic knowledge of the Monti del Sulcis: monte Arcosu (S.W. Sardinia). Flora Mediterranea. 6:157-190.

Naselli Flores L, Barone R, Pasta S, Livreri Console S. 2002. II Gorgo di Santa Rosalia. Studio limnologico e prospettive di conservazione. Unione Europea, Regione Siciliana, Ass. Territorio e Ambiente, R.N. O. 'Monte Pellegrino', Dipartimento di Scienze Botaniche. Palermo: Eurografica.

Olivieri N. 2015. Notulae: 265-278. In: Notulae alla flora esotica d'Italia 12 (244-287). Vol. 47. Informatore Botanico Italiano: Società Botanica Italiana; p. 77-90.

Ostinelli V. 1910. Villa Trabia. Palermo: Tip. Priulla.

Paczkowska G, Chapman AR. 2000. Western Australian Herbarium; Wildflower Society of Western Australia; Botanic Gardens and Parks Authority (WA); Western Australian Herbarium (2000), The Western Australian flora: a descriptive catalogue. Kattidj Close, Kings Park: Wildflower Society of Western Australia: Western Australian Herbarium: CALM: Western Australian Botanic Gardens \& Parks Authority.

Paoletti G. 1900-1902. Fiori A, Paoletti G, editors. Flora analitica d'Italia ossia descrizione delle piante vascolari indigene inselvatichite e largamente coltivate in Italia disposte per quadri analitici, Vol. II. Ed Padova: Tipografia del Seminario, 125.

Pasta S, Badalamenti E, La Mantia T. 2012. Acacia cyclops (A. Cunn. ex G. Don Leguminosae) in Italy: first cases of naturalization. Anales del Jardín Botánico de Madrid. 69:193-200.

Pasta S, La Mantia T. 2008. Le specie vegetali aliene in alcuni SIC siciliani: analisi del grado di invasività e misure di controllo. In: Le specie alloctone in Italia: censimenti, invasività e piani di azione. Memorie della Società Italiana di Scienze Naturali e del Museo Civico di Storia Naturale di Milano. XXXVI(I):79.

Pavari A, De Philippis A. 1941. La sperimentazione di specie forestali esotiche in Italia. Risultati del primo ventennio. Annali della Sperimentazione Agraria. XXXVIII:9-96.

Pignatti S. 1982. Flora d'Italia. Vol. 2. Bologna: Edagricole.

Pizzolongo P. 1960. La flora e la vegetazione di Marina di Ascea (Salerno). I. La Flora. Delpinoa. 2:33-78.
The Plant List [Internet]. 2013. Version 1.1. [accessed 2017 Apr 27]. Available from: http://www.theplantlist.org/.

Puccini G. 1950. Naturalizzazione e riproduzione spontanea di piante ornamentali nella Liguria occidentale. Nuovo Giornale Botanico Italiano. 57:23-33.

Pyšek P, Richardson DM, Rejmánek M, Webster GL, Williamson M, Kirschner J. 2004. Alien plants in checklist and floras: towards better communication between taxonomists and ecologists. Taxon. 53:131-143.

Raimondo FM, Domina G, Spadaro V. 2010. Checklist of the vascular flora of Sicily. Quaderni di Botanica ambientale e applicata. 21:189-252.

Raimondo FM, Domina G, Spadaro V, Aquila G. 2004. Prospetto delle piante avventizie e spontaneizzate in Sicilia. Quaderni di Botanica ambientale e applicata. 15:153-164.

Randall RP. 2012. A global compendium of weeds. 2nd ed. Department of Agriculture and Food, Western Australia. [accessed 2017 Apr 27]. Available from: http://archive.agric.wa.gov.au/objtwr/imported_ assets/content/pw/weed/global-compendium-weeds.pdf.

Richardson DM, Holmes PM, Esler KJ, Galatowitsch SM, Stromberg JC, Kirkman SP, Pyšek P, Hobbs RJ. 2007. Riparian vegetation: degradation, alien plant invasions, and restoration prospects. Diversity and Distributions. 13:126-139.

Richardson DM, Rejmánek M. 2011. Trees and shrubs as invasive alien species - a global review. Diversity and Distributions. 17:788-809.

Ritter M, Yost J. 2009. Diversity, reproduction, and potential for invasiveness of Eucalyptus in California. Madroño. 56:155-167.

Ruwanza S, Gaertner M, Esler KJ, Richardson DM. 2015. Allelopathic effects of invasive Eucalyptus camaldulensis on germination and early growth of four native species in the Western Cape, South Africa. South Forests. 77:91-105.

Sanz-Elorza M, Dana E, Sobrino E. 2001. Listado de plantas alóctonas invasoras reales y potenciales en España. Lazaroa. 22:121-131.

Sena Gomes AR, Kozlowski TT. 1980. Effects of flooding on Eucalyptus camaldulensis and Eucalyptus globulus seedlings. Oecologia. 46:139-142.

Silva-Pando FJ, Pino-Pérez R. 2016. Introduction of Eucalyptus into Europe. Australian Forestry. 79:283-291.

Slee AV, Brooker MIH, Duffy SM, West JG. 2006. Euclid, eucalypts of Australia. 3rd ed. (DVD-Rom). Canberra: Centre for Plant Biodiversity Research.

Stinca A, Croce A, D'Auria G, Salerno G, Santangelo A, Rosati L, Motti R. 2015. Nuovi dati sulla flora vascolare aliena della Campania (Sud Italia). Atti Della Societa Toscana Di Scienze Naturali Memorie Serie B. 122:89-110.

Tererai F, Gaertner M, Jacobs SM, Richardson DM. 2013. Eucalyptus invasions in riparian forests: effects on native vegetation community diversity, stand structure and composition. Forest Ecology and Management. 297:84-93.

Terracciano N. 1876. Cenno intorno al giardino botanico della Real Casa di Caserta ed a certe piante rare che vi si coltivano. Caserta: Nobile e C. Editore.

Terracciano N. 1880. I legnami della Terra di Lavoro al Concorso agrario regionale del 1879 in Caserta. Caserta: Nobile e C.

Tineo V. 1827. Catalogus Plantarum Horti Regii Panormitani ad annum 1827. Palermo: Regale Tip.

Todaro A. 1862. Index seminum Horti Regii Botanici Panormitani quae pro mutua commutatione offeruntur. Palermo: Horti regii botanici Panormitani.

Todaro A. 1868. Index seminum Horti Regii Botanici Panormitani quae pro mutua commutatione offeruntur. Palermo: Horti regii botanici Panormitani.

Todaro A. 1875. Index seminum Horti Regii Botanici Panormitani quae pro mutua commutatione offeruntur. Palermo: Horti regii botanici Panormitani.

Viegi L, Cela Renzoni G, Garbari F. 1974. Flora esotica d'Italia. Lavori Società Italiana di Biogeografia. 4(1973):125-220.

Vilà M, Meggaro Y, Weber E. 1999. Preliminary analysis of the naturalized flora of northern Africa. Orsis. 14:9-20.

Von Holle B, Simberloff D. 2005. Ecological resistance to biological invasion overwhelmed by propagule pressure. Ecology. 86:3212-3218.

Western Australian Herbarium (1998). FloraBase-the Western Australian Flora. Department of Parks and Wildlife. [accessed]. Available from: https://florabase.dpaw.wa.gov.au/. Release date for FloraBase 2.9.21.Thursday 2 March 2017. 